China Perspectives

63 | january - february 2006

Varia

\title{
Reforms, Structural Adjustments, and Rural Income in China
}

\section{Weiyong Yang}

\section{(2) OpenEdition}

1 Journals

Édition électronique

URL : http://journals.openedition.org/chinaperspectives/575

DOI : 10.4000/chinaperspectives.575

ISSN : 1996-4617

Éditeur

Centre d'étude français sur la Chine contemporaine

\section{Édition imprimée}

Date de publication : 1 février 2006

ISSN : 2070-3449

Référence électronique

Weiyong Yang, "Reforms, Structural Adjustments, and Rural Income in China », China Perspectives [En ligne], 63 I january - february 2006, mis en ligne le 01 février 2009, consulté le 28 octobre 2019. URL: http://journals.openedition.org/chinaperspectives/575; DOI : 10.4000/chinaperspectives.575

Ce document a été généré automatiquement le 28 octobre 2019

(C) All rights reserved 


\title{
Reforms, Structural Adjustments, and Rural Income in China
}

\author{
Weiyong Yang
}

1 Since the founding of the People's Republic, China's rural economy has experienced many twists and turns linked to the frequent political movements characteristic of the Maoist period, such as the Great Leap Forward and the Cultural Revolution. From 1958 onwards, the Chinese countryside was organised into people's communes, in which all decisions affecting production, consumption, and even the daily lives of the peasantry, were taken in accordance with the current five-year plan. At that time the rural economy, dominated by grain production, was characterised by low levels of productivity and income. At the end of the 1970s China entered its period of economic reforms. The people's communes were dismantled and market mechanisms were gradually introduced. This meant a considerable shift in the rural economy, from being based mainly on agricultural (mostly grain) production, to becoming a diversified economy combining agricultural and non-agricultural activities. This article will analyse the impact of these structural changes on rural income.

The structural changes in the rural economy

2 Since 1978, the structure of the rural economy has become diversified at several different levels. Firstly grain production (rice, wheat, maize, millet, soy beans, and root vegetables) has gradually made way for commercial growing (vegetables, fruit, peanuts, oilseed, beetroots, etc.). The second major change was the rapid development of rural industries.

Grain production versus growing for the market

3 Throughout the Maoist era, the Chinese government was extremely concerned with securing the nation's food supply, so they established a policy of self-sufficiency giving a major role to the production of grain, which was the population's staple diet ${ }^{1}$. Grain dominated agricultural production, and throughout that period the proportion of land reserved for growing grain was kept very high, never falling below $80 \%$ of the total. This predominance was sustained partly by the collective system of production, in which the allocation of productive resources (particularly arable land) was laid down in 
pre-established plans, and partly, in the absence of market mechanisms, by the unified system of distribution ${ }^{2}$.

4 The introduction and widespread application of the family responsibility system in the early 1980 s led to the decollectivisation of agricultural production. Since the peasants acquired the right to exploit the land for themselves, this gave them a certain freedom to choose their crops, so the household again became the place where decisions on production could be taken independently, with the only proviso that the state-imposed quotas had to be fulfilled. In general, the freedom to choose crops grew in step with the development of the reforms.

5 Along with these developments, the system for putting agricultural products onto the market also became liberalised. Starting from 1979, the prices of agricultural products fixed by the state were revised upwards in stages, and by the 1990s they were close to the free market prices. At the same time, the market system underwent rapid development and became a major outlet for agricultural produce. In 1995, 37\% of all grain production was sold through the open market ${ }^{3}$, and the average peasant family sold around 350 kilos annually in this way ${ }^{4}$. Within this liberalising context, the choice of which crops to cultivate became increasingly determined by economic factors, and especially by the development of price differences for different products.

6 The continuing process of opening up to foreign trade has also had a major influence. On the one hand, the arrival and increasing intensity of foreign competition is pushing China to adjust the weighting given to different crops according to their comparative advantages. Since the country has an abundance of labour but a dearth of arable land, it is obliged to reduce the production of grain requiring a lot of land in favour of more labour-intensive commercial crops. On the other hand, the open door policy allows the purchase of foodstuffs on the international market, and this makes the government less anxious about the security of supply, while also enabling an easier transition from grain to more commercial crops.

7 For these reasons grain production has continually fallen in comparison with commercial crops, and between 1978 and 2003 its share of the total land area for sowing grain has shown a general tendency of decrease (see Graph 1). However this development has been affected by glitches in the reform process and other extraneous factors causing fluctuations in grain production. For example, in the early 1980s, the introduction of the family responsibility system, the relaxation of the system of food production quotas, and the emergence of the market economy, all combined to bring about a rapid fall in grain production. This moved from taking up $80.3 \%$ of the utilised land in 1978 to $75.8 \%$ in 1985, but it was followed by two slight increases, in 1986 and 1989-91 respectively, both periods being times when a series of "anti-market" administrative measures were taken in order to boost grain production and strengthen the obligatory quota system. 

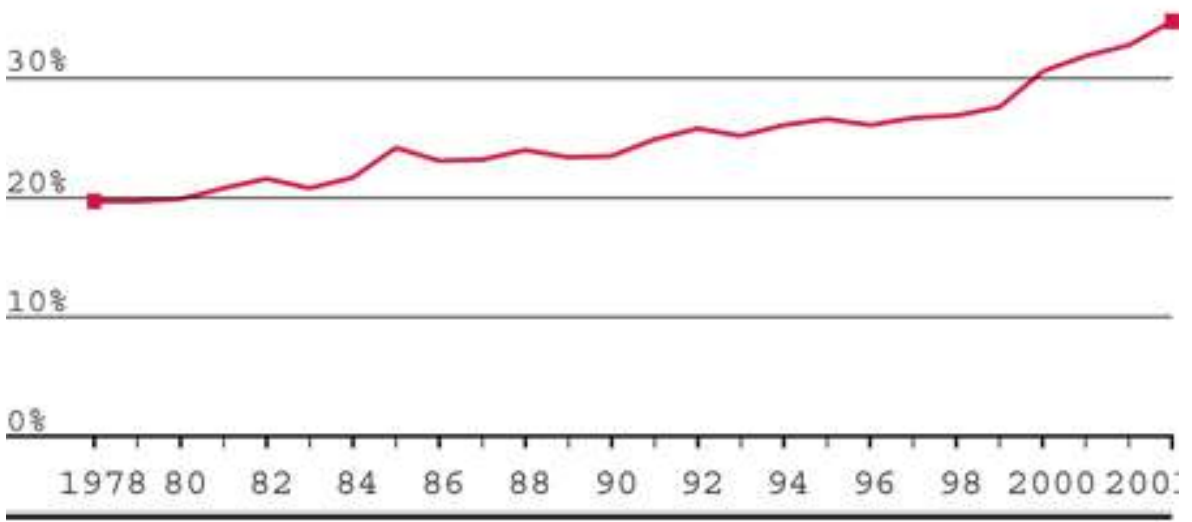

Source: National Bureau of Statistics of China, Chin China Statistics Press, 1991 and 2004.

In the early 1990s, the pursuit of the reform goals and the total liberalisation of the agricultural market saw a return to the developments in favour of commercial crops. However, sagging grain production and the rising price of grain in the mid-1990s reawakened governmental concerns over the issue of securing the food supply. In 1995 it reintroduced the obligatory system, making provincial governors responsible for their province's self-sufficiency in grain, irrespective of the local farming conditions. The process of adjusting the agricultural structures slowed down, before picking up again recently. In 2003, the share of commercial crops in the overall cultivated area reached $34.8 \%$ (see Graph 1), and the diminution of the area for grain production led to a substantial fall in production. Between 1998 and 2003 annual grain production fell from 512.3 to 430.7 million tons, and from $412 \mathrm{~kg}$ to $334 \mathrm{~kg}$ per head. In conjunction with the continuing rise in consumption, this development caused sharp rises in the price of grain in 2004-in the first three quarters prices rose by $28.4 \%$. The effect of these increases was to encourage the peasant households to increase the amount of land given over to grain production.

9 Developments at the national level conceal large regional disparities (see Graph 2). Throughout the period from 1978 to 2003, it was in the west, where natural conditions are the most varied, that the changes in the structures of agricultural production (measured in terms of the ratio between the acreages for commercial crops and for grain production) advanced most rapidly. Next in line were the coastal areas, where the economic reforms were the most developed, and last was the central region, the traditional area of grain production. That is why the west, which in the late 1970s had the lowest proportion of commercial crops, has since the late 1990s caught up and overtaken the central region. Since 1986, the coastal region has maintained its lead, and has even increased this lead in recent years. 


\section{Development by Region in the Ratio between Commercial Crops and Grain}

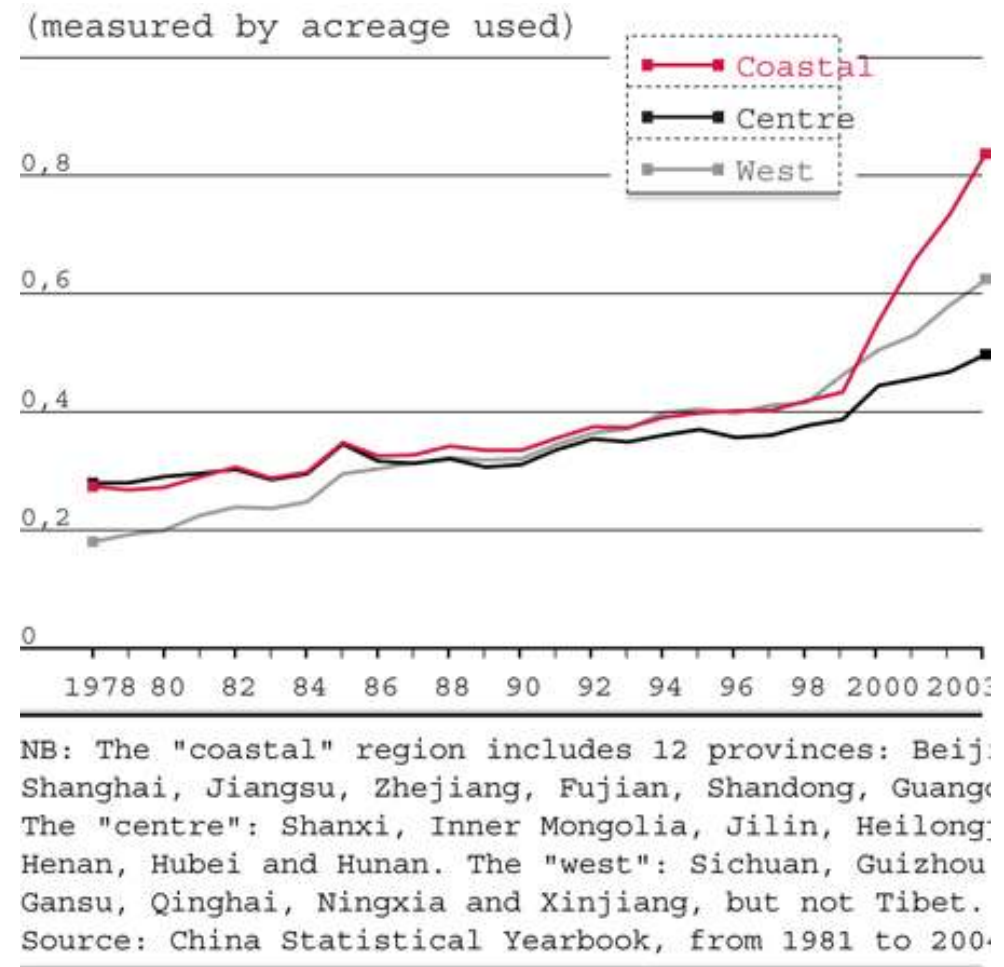

The development of rural enterprises

The development of the rural enterprises ${ }^{5}$ since the 1980s has profoundly altered life in the countryside. From 1978 to 2003, the real value of output from the rural enterprises increased annually by $23.2 \%$. This strong growth rate has radically transformed the rural economy, which was traditionally based on agriculture. In 1978 the gross product of the rural enterprises outstripped agriculture. By the late 1990s, the rural enterprises became the leading added value sector. In 2000 that value amounted to $2,715.6$ billion yuan, which represented $64 \%$ of rural GDP ${ }^{6}$, and over $30 \%$ of the national GDP. The number of workers employed by the rural enterprises rose from 28.3 million in 1978 to 135.7 million in 2003 (that is, from 9.2\% to $28.1 \%$ of the total active rural population) ${ }^{7}$.

11 The industrialisation of the countryside dates back to the Maoist era, when workshops to repair agricultural implements and communal enterprises were set up, to support agricultural production. The decollectivisation in the countryside and the decentralisation of fiscal management in the early $1980 \mathrm{~s}^{8}$ made a significant contribution to the rapid take-off of the rural so-called "township and village" enterprises (xiangzhen qiye). Their development was not smooth, being tightly constrained by progress of the reforms. After a strong growth period between 1984 and 1988, the rural enterprises experienced a period of recession from 1989 to 1991. Several million employees returned to agricultural work as a consequence of huge numbers of closures (see Graph 3). But from 1992 to 1996 the acceleration of the reforms brought about widespread prosperity among the rural enterprises. Since 1997, following internal and external difficulties, the rural enterprises have entered into a phase of restructuring marked by a slowing rate of growth in both output and employment. 


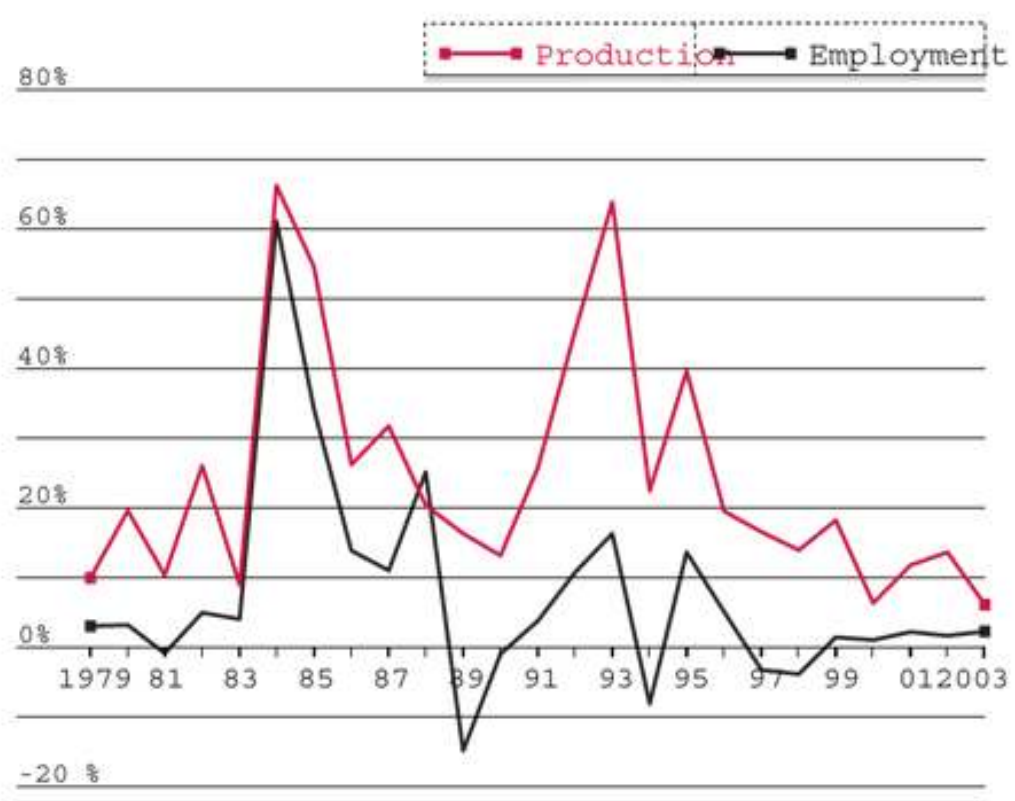

Source: Township and Village Enterprise Yearbook, Bei.

different years.

12 Seen from a regional perspective, the development of industry in the countryside is extremely unbalanced. Rural enterprises arise and prosper above all in the coastal provinces ${ }^{9}$, which in 1982-2003 had a dominant position in terms of both employment (over $50 \%$ ) and output value (over $60 \%$ ). In terms of the rural enterprises' share in overall job-creation in the countryside, the gap between the coast on the one hand and the west on the other, remained constant before widening further in recent years.

Property rights legislation governing the rural enterprises are being transformed in tandem with the developments in social institutions. In the 1980s the rural enterprises were essentially owned collectively and run by the local governments of the townships and villages. Collective enterprises afforded many advantages in terms of obtaining operating licences, protection from political attack, and access to credit facilities, raw materials, and markets. In contrast with this, the 1990s saw the rising power of the private enterprises. With the deepening of the reforms and the growth of the market system, the collective enterprises lost their competitive advantage and suffered more and more from the intrinsic difficulties arising from their poorly defined status in terms of property rights. From 1991 to 2003 there was a distinct slowing in the growth of the collective enterprises, especially with regard to employment. Their ability to take on labour reached its zenith in 1995 (60.6 million employees), before falling by $7.2 \%$ annually in the following years. Throughout the decade, the private firms continued to experience more rapid growth than the collectives, in terms of both employment and output. Between 1991 and 2001, the annual growth rate in production for private firms was double that of the collective enterprises (33.9\% as against $15.2 \%$ ). In terms of employment the private firms likewise saw an annual increase of $7.2 \%$, whereas the collectives showed an annual decrease of $3.4 \%$ for the same period. Thus the private enterprises took over from the collective enterprises, becoming the leading 
and most dynamic sector of the rural economy. In 2002, 96.6\% of rural enterprises were privately owned, and played a dominant role in both employment and added value (71.8\% and $62.7 \%$ respectively).

14 In sum, since the introduction of the reforms in the late 1970s, the rural economy has undergone profound structural transformation, from grain production to production for the market and diversification into non-agricultural activities, but this has involved wide regional disparities. In general, development has been more pronounced in the coastal provinces, especially in the south-west where the economic reforms have gone further than elsewhere. By way of contrast, the central and western regions of the country are significantly behind.

Developments in rural income

The structural transformations have been accompanied by sharp increases in rural income. Real per capita income in the countryside rose by an annual average of $6.4 \%$ between 1978 and 2003, as compared with a mere 1.7\% for 1957-1977 (see Table 4). Between 1978 and 1984, following the introduction of the family responsibility system in the agricultural sector, rural incomes rose by the exceptionally high rate of just over $14.2 \%$ per year, before slowing to just over $1.9 \%$ in the second half of the 1980 s because of the obstacles to the reforms after 1986. During the period of the setback to the reforms (1989-1991) characterised by an extremely restrictive macro-economic policy, the growth in rural incomes stagnated at just over $0.6 \%$, and 1989 even showed a decline of 7.4\% in relation to the previous year. The subsequent recovery of the reforms brought about a new strong growth rate of just over 7.9\% between 1992 and 1996 . However, since 1997, under the combined effect of the Asian financial crisis and the stagnation of the collective rural enterprises, the rural growth rate has slowed, registering just over $4.2 \%$ for 1997-2003. This situation has become a major cause of concern to the government, given its anxiety to ensure a balance in the development of the cities and the countryside, and to maintain social stability. 
(in \%)

\begin{tabular}{|c|c|c|c|c|}
\hline Period & National & Coastal & Centre & West \\
\hline $1957-1977$ & 1.7 & & & \\
\hline $1978-2003$ & 6.4 & 6.8 & 6.1 & 5.3 \\
\hline $1978-1984$ & 14.2 & 15.5 & 15.5 & 13.2 \\
\hline $1985-1988$ & 1.9 & 2.5 & -1.2 & 2.5 \\
\hline 1989-1991 & 0.6 & 1.7 & -0.6 & -0.5 \\
\hline $1992-1996$ & 7.9 & 6.7 & 8.8 & 2.8 \\
\hline $1997-2003$ & 4.2 & 4.6 & 3.8 & 4.8 \\
\hline
\end{tabular}

NB: The recorded growth rate is the annual geometric over a period. The three regions are specified in $\mathrm{Gr}$ Source: China Statistical Yearbook, different years.

The coastal region has enjoyed the highest income throughout the reform period, followed by the centre and the west (see Graph 5). In terms of the annual growth rate, income has also increased most rapidly, at $6.8 \%$ per year, in the coastal region. In the west, the growth rate has been the slowest throughout the whole period from 1978 to 2003. The central region appears to be the most sensitive to changes in the reform process. In the early phase (1978-1984) and during the phase of acceleration (1992-1996), the central region experienced the highest growth rate of all the three regions, although in the periods of arrest (1986-1988) and retreat (1989-1991) it showed the slowest growth rates, and even went into reverse towards the end of the 1980s. The regional disparities in rural income have widened, particularly between the coastal region and the rest of the country (see Graph 5). In this respect it is instructive to compare 1978, when the rural income of the coastal region was $56 \%$ higher than that of the west, with 2003, when the gap widened to $124 \%$. 


\section{Regional Disparities in Rural Incomes}

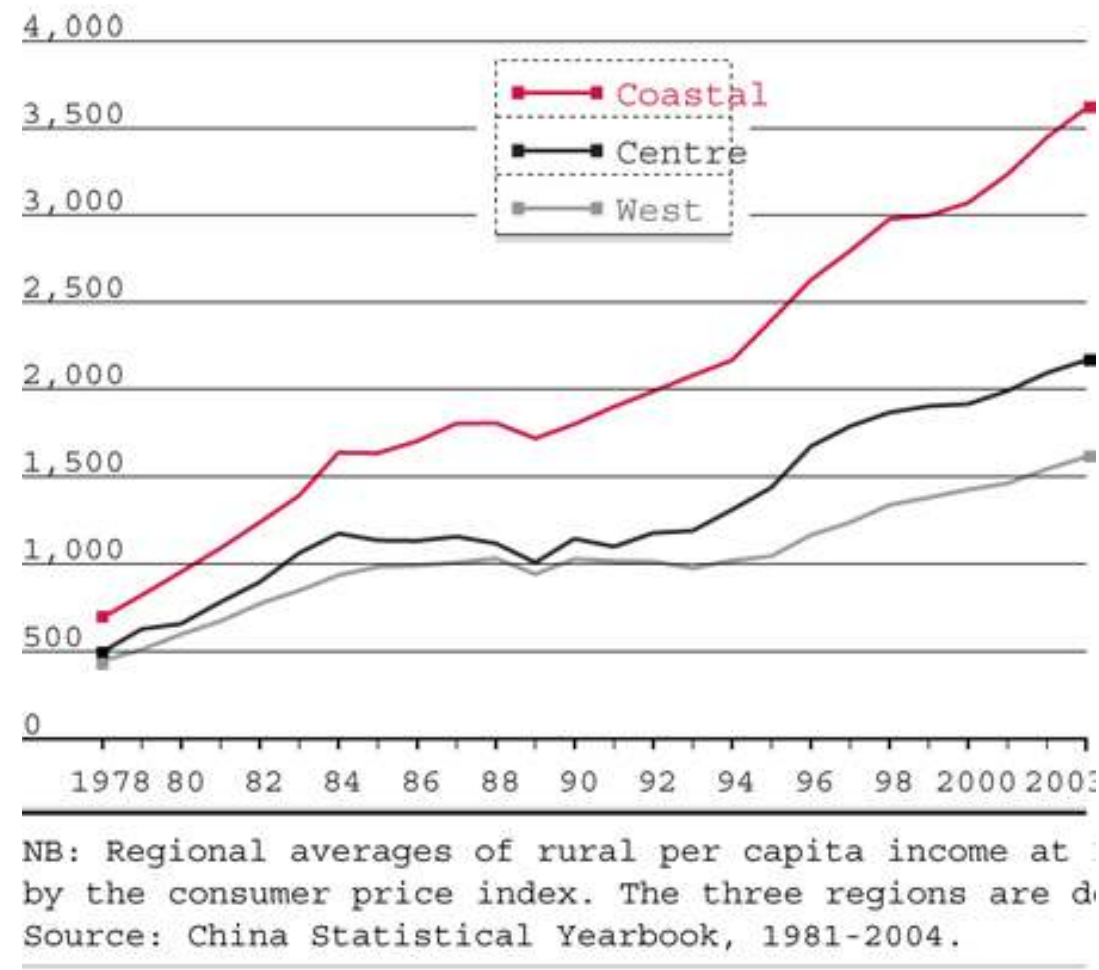

Structural transformations and rural income

There is a constant ambiguity in the relationship between structural transformations and income, for the changes may well entail a decrease in rural income owing to the costs of the adjustments ${ }^{10}$. New undertakings demand fixed non-recoverable capital investment. For example, changing from one kind of crop to another calls for the preparation of the land or the irrigation system, and the launching of non-agricultural ventures requires a certain amount of capital, not to say education or training ${ }^{11}$. Such adjustment costs may indeed reduce the income of the rural inhabitants, at least in the short term.

But these transformations can also favour an increase in income, thanks to the complementarities between the different activities. Changing from one crop to another can allow certain specific local conditions, like the variable nature of the soil or the climate, to be turned to one's advantage ${ }^{12}$. Similarly, the development of nonagricultural activities can be beneficial because of the links between agriculture and rural industry ${ }^{13}$. For example, activities which make use of agricultural products as their raw materials ${ }^{14}$ can benefit from the availability and variety of fresh produce. Conversely, agriculture can benefit from non-agricultural enterprises which produce the trainees and equipment needed by agriculture. Furthermore, some of the profits created by the rural enterprises can be reinvested in agriculture. Such complementarities is even more important in the case of seasonal needs ${ }^{15}$; households can put their resources by turns into agricultural and non-agricultural activities, and they can also switch between different kinds of crop in accordance with local soil conditions.

19 Before 1978, the imposition of exclusive grain cultivation, maintained by administrative measures, meant that resources were used inefficiently, agricultural 
productivity and incomes were low, and there was a large manpower surplus. In this respect, the transformations over the last twenty years can be seen as a process of reallocating resources in a more efficient way. With the development of market mechanisms, the allocation of productive resources is increasingly guided by the principle of profitability. So excess agricultural manpower can be utilised in other activities. In the overall context of market liberalisation and opening to foreign trade, and in a country with a land shortage but an abundance of manpower, this development represents a better utilisation of the country's relative advantages. Consequently, the structural transformations enable a general improvement in labour productivity and an increase in income.

Graph 6 shows the relations between the structural transformations and the growth in income since 1978. Their parallel development suggests that the reallocation of resources, from grain cultivation to growing for the market, in accordance with local agronomic conditions and the market situation, has enabled the productivity for the whole sector to be improved. Likewise, the developments in the structure of rural employment follow the same pattern as income. In fact, it is the incomes produced by rural industry which have experienced the strongest growth rates since the mid-1980s ${ }^{16}$. In 2003 , an average of $35.4 \%$ of per capita rural income came from the rural enterprises, as opposed to $33.8 \%$ and $9.4 \%$ for agriculture and animal husbandry respectively. Between 2002 and 2003, the rural enterprises contributed up to $50 \%$ per capita of the total growth in rural income ${ }^{17}$. As Claude Aubert has shown ${ }^{18}$, whereas income from the agricultural sector has been stagnant since the mid-1990s, income from the non-agricultural sector has regularly increased to become the major source of rural income in the same period. In 2003, out of an average per capita rural income of 2,622 yuan, the proportion represented by non-agricultural activity reached $54.4 \%$, as opposed to $45.6 \%$ for all agricultural activities (cultivation, husbandry, fisheries, and forestry). 
6. Structural Adjustments in Rural Incomes

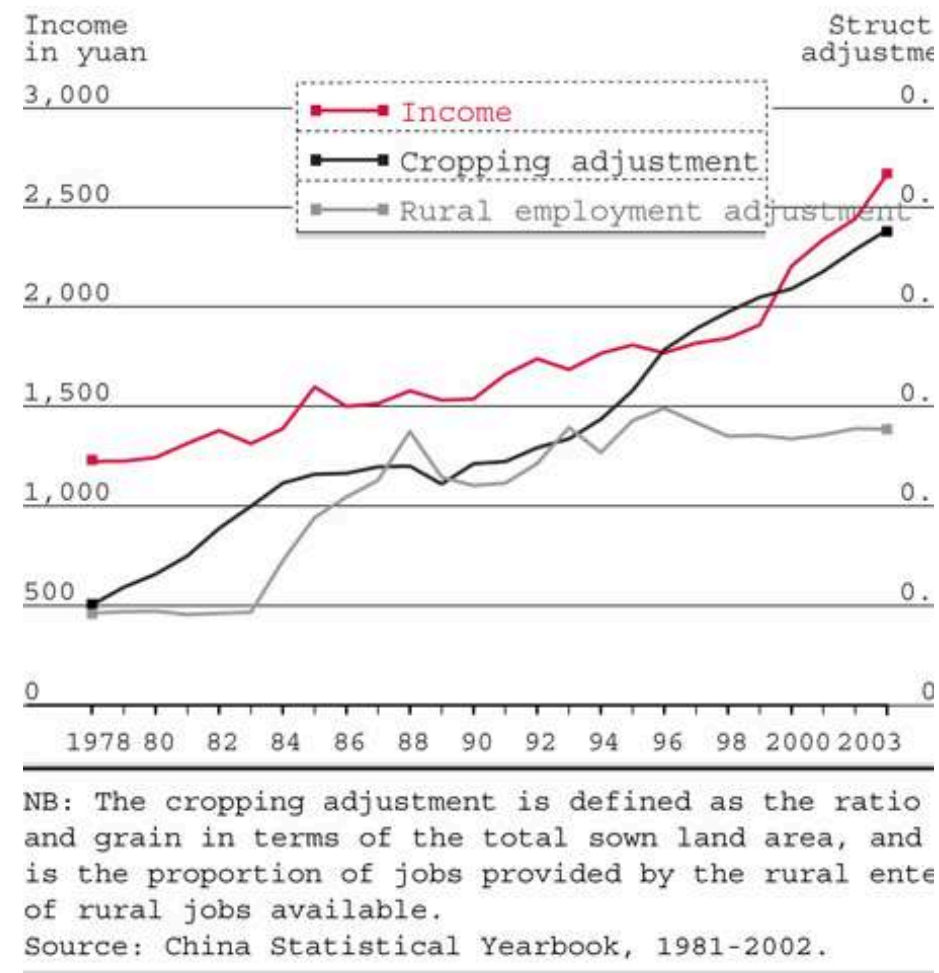

Based on data gathered from 29 Chinese provinces for 1982-2003, an econometric test has established the relations between the structural transformations and the changes in per capita income (see Table 7). The positive coefficients related to the move from grain to commercial harvests on the one hand, and to the development of nonagricultural activities on the other, show that these two developments made a very significant contribution to the increase in rural income ${ }^{19}$. This result suggests that the benefits from the structural transformations have more than compensated for the costs entailed by the adjustments. The two adjustments would appear to have allowed a more efficient allocation of productive resources on the one hand, and a capacity to take advantage of the complementarities between the different rural activities on the other. These beneficial effects upon rural income as a whole seem to outweigh the negative factors, particularly the short-term investments needed to bring about the changes in economic activity. 
7. Estimated Impact of the Structural Adjustments on Rural Incomes

\begin{tabular}{|c|c|}
\hline Variables & $\begin{array}{l}\text { Revenu } \\
\text { (including variab }\end{array}$ \\
\hline Cropping adjustment & $\begin{array}{l}565.27 \\
(5.56) *\end{array}$ \\
\hline Employment adjustment & $\begin{array}{l}613.45 \\
(3.58) *\end{array}$ \\
\hline Constant & $\begin{array}{r}-2561.75 \\
(-5.65) \star\end{array}$ \\
\hline Number of observations & 632 \\
\hline R2 (within) & 0.75 \\
\hline Method of calculation & Fixed effect \\
\hline \multicolumn{2}{|c|}{$\begin{array}{l}\text { NB: * T-Student values. } \\
\text { The cropping adjustment is measured in terms of the } r \\
\text { commercial crops and grain on the basis of the sown } 1 \\
\text { and the employment adjustment is defined as the propo } \\
\text { by the rural enterprises out of the total number of } j \\
\text { The variables taken into account are the following: r } \\
\text { measured as the ratio between population numbers and } \\
\text { of the province; dependency ratio, the average number } \\
\text { members per worker; irrigation, the proportion of irr } \\
\text { out of the total area used for crops; land rotation, } \\
\text { and the total available arable land in each province; }\end{array}$} \\
\hline
\end{tabular}

Throughout the reform period, the rural economy has undergone major structural changes on several levels, all of which are involved in the shift from grain production towards a development of growing for the market, and a vigorous development of the rural enterprises. But major regional disparities still persist. In general, the adjustments have been quicker and more far-reaching in those regions where the reforms have gone the furthest, as in the south and east of the country.

These adjustments have been accompanied by a steep rise in rural incomes. In view of their major positive contribution to this increase, the adjustments to the structure of agriculture and rural employment should be encouraged, in order to enable sustainable long-term rural development. Moreover, these adjustments are proving increasingly imperative in the face of the intensifying international competition following China's joining the WTO. In this new situation, the adjustments in the rural economy accord with the country's comparative advantages. Since 2001, there have been reports of a big rise in grain imports (of wheat and soy beans in particular), but on the other hand there has been a remarkable expansion in the export of manufactured goods, particularly textiles, most of which have been produced in the rural enterprises following the abolition of quotas in 2005. All levels of government have played a major role in these structural transformations, by supplying information on national and overseas markets on the one hand, and by granting subsidies or preferential credits on the other, thus allowing the costs involved in the necessary structural adjustments to be overcome.

Translated from the French original by Jonathan Hall 


\section{NOTES}

1. In China in $1952,94.1 \%$ of the calories and $95.5 \%$ of the protein in the average daily diet came from a vegetable source, mostly grain: Ministry of Agriculture (MoA), Zhongguo nongcun jingji tongji daquan 1949-1986 (Statistics on the rural economy 1949-1986), Beijing, Nongye chubanshe, 1989, p. 580.

2. In 1957 the government abolished the free markets in the countryside (see Jean C. Oi, "The Role of the Local State in China's Transitional Economy", The China Quarterly, Vol. 144, December 1995, pp. 1132-1149).

3. John Davis and Liming Wang, "The Economic Behaviour of China's Grain Producers in Transition", in Sarah Cook, Shujie Yao, and Juzhong Zhuang (eds.), The Chinese Economy under Transition, Basingstoke, Palgrave Macmillan, 2000, pp. 198-217.

4. Bingsheng Ke (ed.), China's Grain Market and Policy, Beijing, China's Agricultural Press, 1995.

5. The activities of these rural enterprises are very extensive and cover most economic sectors: the finishing of agricultural products, building, mining, manufacture, transport and other services.

6. Township and Village Enterprise Yearbook, Beijing, China Agricultural Press, 2001.

7. Township and Village Enterprise Yearbook, Beijing, China Agricultural Press, 2004.

8. Christine P. W. Wong, Christopher Heady, and Wing Thye Woo (eds.), Fiscal

Management and Economic Reform in the People's Republic of China, Oxford, Hong Kong, and New York, OUP, 1995.

9. In 1985, and likewise in 2003, the five coastal provinces (Fujian, Guangdong, Jiangsu, Zhejiang, and Shandong) accounted for $50 \%$ of the national production from rural enterprises (Township and Village Yearbook, Beijing, China Agricultural Press, 1987 and 2004).

10. David R. Lee and Christopher B. Barrett (eds.), Tradeoffs of Synergies? Agricultural Intensification, Economic Development, and Environment, New York, CABI, 2001. 11. Christopher B. Barrett, Thomas Reardon, and Patrick Webb, "Non-Farm Income Diversification and Household Livelihood Strategies in Rural Africa: Concepts, Dynamics, and Policy Implications", Food Policy, Vol. 26, 2001, pp. 315-331; Tashew Woldehanna and Arie Oskam, "Income Diversification and Entry Barriers: Evidence from the Tigray Region of Northern Ethiopia", Food Policy, Vol. 26, 2001, pp. 351-365. 12. Benoît Blarel, Peter Hazell, Frank Place, and John Quiggin, "The Economics of Farm Fragmentation: Evidence from Ghana and Rwanda", World Bank Economic Review, Vol. 6, No. 2, 1992, pp. 233-254.

13. Peter Hazell and Stephen Haggblade, "Farm-Non-Farm Growth Linkages and the Welfare of the Poor" in Michael Lipton and Jacques van der Gaag (eds.), Including the Poor, Proceedings of a Symposium Organized by the World Bank and International Food Policy Research Institute, Washington D.C., World Bank, 1993, pp. 190-204.

14. In 1995, out of all the township and village enterprises, those which used farm products as raw materials represented $34 \%$ (64\% in the light industry sector) in terms of the number of enterprises involved, $26 \%$ (53\%), in terms of job provision, and $27 \%$ (55\%) in terms of overall production.

15. David E. Sahn (ed.), Seasonal Variability in Third World Agriculture: The Consequence for Food Security, Baltimore, Maryland, Johns Hopkins University Press, 1989; Bina Agarwal, 
"Social Security and the Family: Coping with Seasonality and Calamity in Rural India", Journal of Peasant Studies, Vol. 17, 1990, pp. 341-412.

16. Hongyi Chen (ed.), The Institutional Transition of China's Township and Village Enterprises: Market Liberalisation, Contractual Form Innovation, and Privatisation, Aldershot, Ashgate, 2000.

17. Township and Village Enterprise Yearbook, 2004.

18. Claude Aubert, "Le devenir de l'économie paysanne en Chine", Revue Tiers Monde, Vol. 46, No. 183, pp. 491-515.

19. The statistical significance of the coefficients in these calculations is measured in TStudent values. A T-Student (absolute value) of over 1.96 is the precondition for a statistical significance of over $95 \%$. In other words, it can be asserted with more than 95\% certainty that the explanatory variable has statistically important effects upon the dependent variable. In the present case, the coefficients of the two structural adjustment variables have T-Student values distinctly higher than the 1.96 threshold. This means that the positive impact of these adjustments is statistically significant.

\section{RÉSUMÉS}

Since the beginning of the reforms in 1978, China's rural economy has undergone considerable structural change. This article will analyse these changes as they affect China's agriculture and the development of its non-agricultural activities. It will look at the history of these developments, the regional imbalances, and the consequences of both for the rural economy. 